\title{
INTERAKSI SOSIAL DALAM KEJADIAN ABORTUS PROVOKATUS KRIMINALIS DI KABUPATEN BULUKUMBA PROVINSI SULAWESI SELATAN
}

\author{
Rizal Ridwan ${ }^{1}$, Shinta Prawitasari ${ }^{2}$, Leo Prawirodihardjo ${ }^{3}$
}

\begin{abstract}
Background: Many factors influence the decision to commit abortions, among all are marital status and educational status which most are still in school, economic pressure, multiparity or contaception failure. The social interaction is a connection between $t$ the people who perform abortion and their suggestive environment.

Objective: to observe the social interaction that happend among the person who perform abortion and the surrounding society.

Method: This research makes use of qualitative method to understand the motives behind abortion practice, through an indepth interview. The sample collection is performed on H. A. Sulthan Dg Radja Hospital and Daffiku Hospital Bulukumba.

Result and Discussion: Subject who performed abortion was influenced by internal and external factors. The internal factors include anxiousness, financial worrisome to support the child and fear of embarrassing the family in an unmaried women. As for the external factor includes pressure from families and friends who insist on performing abortion and the help from traditional healer on performing abortion. These two factors are not independent, and between them there are interactions to materialize abortion practice. Conclussion: Social interaction between individuals and between individual and the environment are an important role against abortion in decision making to have an provocative abortion.
\end{abstract}

Keywords: Social interaction, abortion, factors for abortion

\begin{abstract}
ABSTRAK
Latar Belakang: Berbagai faktor mempengaruhi keputusan melakukan aborsi, diantaranya masih sekolah atau kuliah dan belum menikah, desakan faktor ekonomi, jumlah anak yang banyak atau kegagalan kontrasepsi. Interaksi sosial pada pelaku aborsi adalah hubungan antara pelaku aborsi dengan lingkungan yang mempengaruhi orang tersebut melakukan tindakan aborsi.

Tujuan: mengetahui interaksi sosial yang terjadi antara pelaku aborsi dengan masyarakat sekitarnya.

Metode: Penelitian ini menggunakan metode kualitatif untuk mngetahui motivasi dalam melakukan aborsi, melalui teknik wawancara mendalam (indepth interview). Pengambilan sampel dilakukan di RSUD H. A. Sulthan Dg Radja Kab. Bulukumba dan Rumah Bersalin DaffiKu Kab. Bulukumba.

Hasil dan Pembahasan: Subjek yang melakukan aborsi disebabkan oleh faktor internal dan eksternal. Faktor internal meliputi rasa cemas, takut membiayai anak yang kelak dilahirkan, dan takut karena telah membawa aib bagi keluarga pelaku aborsi yang belum menikah. Adapun faktor eksternal yang mempengaruhi subjek
\end{abstract}

Departemen Obstetri dan Ginekologi RSUD Bulukumba, Sulawesi Selatan

Departemen Obstetri dan Ginekologi Fakultas Kedokteran, Universitas Gadjah Mada Yogyakarta.

RSDKIA Siti Fatimah, Makassar, Sulawesi Selatan

Korespondensi: e mail: rizalridwandappi@gmail.com 
melakukan aborsi adalah adanya desakan dar keluarga atau teman yang mendorong untuk melakukan tindakan aborsi dan adanya dukun yang bersedia membantu melakukan aborsi. Kedua faktor tersebut tidak berdiri sendiri, melainkan saling berinteraksi untuk mewujudkan perilaku aborsi.

Kesimpulan: Interaksi sosial antara individu dengan individu dan individu dengan lingkungan berperan penting terhadap pelaku aborsi dalam pengambilan keputusan melakukan aborsi provokatus.

Kata kunci: interaksi sosial, aborsi, faktor-faktor aborsi

\section{PENDAHULUAN}

Setiap tahun berjuta-juta perempuan Indonesia mengalami kehamilan yang tidak direncanakan, dansebagian besar dariperempuan tersebut memilih untuk mengakhiri kehamilan mereka, walaupun dalam kenyataannya aborsi provokatus kriminalis secara umum adalah ilegal. Seperti di Negara-negara berkembang lainnya dimana terdapat pembatasan yang ketat terhadap aborsi provokatus kriminalis, perempuan Indonesia sering kali mencari bantuan untuk aborsi provokatus kriminalis melalui tenagatenaga non-medis yang menggunakan cara-cara antara lain dengan meminum ramuan-ramuan yang berbahaya dan melakukan pemijatan penguguran kandungan yang membahayakan. ${ }^{1}$

Tiap tahun, di seluruh dunia, terdapat 42 juta perempuan yang mengalami kehamilan yang tidak diinginkan memilih untuk melakukan aborsi. Separuh dari tindakan aborsi ini tidak aman. Kurang lebih 68.000 perempuan meninggal karena aborsi yang tidak aman tiap tahunnya dan itu menyumbang kematian ibu sekitar $13 \%$ nya. ${ }^{2}$ Say et al. menyebutkan bahwa antara tahun 2003- 2009 sekitar 7,4\% angka kematian ibu di Asia Tenggara terjadi akibat aborsi. ${ }^{2}$

Ada beberapa faktor pendorong timbulnya aborsi provokatus kriminalis yaitu (1) desakan faktor ekonomi jika tidak melakukan aborsi (2) jumlah anak yang banyak atau kegagalan kontrasepsi (3) putus hubungan kerja ( PHK ) bila tidak melakukan aborsi dan (4) masih sekolah atau kuliah dan belum menikah. ${ }^{3}$ Permasalahan dalam penelitian ini yaitu bagaimanakah peran interaksi sosial dalam pengambilan keputusan untuk melakukan abortus provokatus kriminalis?. Tujuan penelitian ini adalah untuk mengetahui interaksi antara pelaku aborsi provokatus kriminalis dengan suami dan keluarga, mengetahui interaksi sosial pelaku aborsi provokatus kriminalis dengan teman sebaya dan mengetahui motivasi dalam melakukan aborsi provokatus kriminalis.

\section{METODE}

Penelitian ini menggunakan metode kualitatif. Seleksi calon informan dilakukan dari pasien-pasien aborsi provokatus kriminalis dengan memperhatikan status pernikahan. Setelah itu dilakukan wawancara mendalam terhadap informan-informan tadi lalu dilakukan pengumpulan dan pengolahan data hasil wawancara mendalam tersebut. ${ }^{4}$

Penelitian ini menggunakan rancangan penelitian penjelasan (Explanatory research), melibatkan informan wanita pelaku aborsi dengan kriteria : usia 18-40 tahun menikah atau belum menikah yang berasal dari latar belakang sosial demografi yang berbeda.

Metode pengumpulan datan ya adalah wawancara, masing-masing 5 sampel diambil secara acak dari populasi usia remaja yang belum menikah dan populasi wanita yang sudah berkeluarga yang mengalami aborsi provokatus kriminalis di RSUD H. A. Sulthan Dg Radja Kab. 
Bulukumba dan Rumah Bersalin DaffiKu Kab. Bulukumba.

Ada tiga kelompok pertanyaan yang diajukan di dalam wawancara mendalam untuk mengetahui tujuan penelitian yaitu

(1) kelompok pertanyaan untuk mengetahui interaksi antara pelaku aborsi provokatus kriminalis dengan suami dan keluarga yang terdiri atas pertanyaan (a) hubungan informan dengan keluarga, (b) jumlah saudara dan status tempat tinggal, (c) hubungan informan dengan suami/pacar dan kapan terakhir kali anda berhubungan intim dengan pasangan serta apakah pasangan informan memakai pengaman (kondom) saat berhubungan intim, (d) bagaimana reaksi keluarga saat pertama kali mengetahui informan hamil? Apakah ada anggota keluarga yang memaksa informan melakukan aborsi?, dan (e) bagaimana kondisi ekonomi keluarga informan saat ini

(2) kelompok pretanyaan untuk mengetahui interaksi sosial pelaku aborsi provokatus kriminalis dengan teman sebaya: (a) Bagi yang belum menikah, mengapa anda bisa menjadi korban pergaulan bebas atau semacamnya?, (b) Hubungan informan dengan masyarakat sekitar dan reaksi dari masyarakat atas kejadian aborsi, (c) Apakah informan pernah mendapatkan pengetahuan mengenai pergaulan bebas?, dan (d) Apakah informan pernah berhubungan dengan narkoba, minuman beralkohol dan rokok?

(3) kelompok pertanyaan untuk mengetahui motivasi dalam melakukan aborsi provokatus kriminalis: (a) apa alasan informan melakukan aborsi (b) kapan informan melakukan aborsi dan berapa usia kehamilan informan saat itu (c) Apa yang informan rasakan ketika ingin melakukan aborsi dan secara fisik apakah informan merasa sakit ketika melakukan aborsi (d) Apakah informan pernah berusaha minum obat-obatan yang dapat menggugurkan kandungan atau berusaha melakukan aborsi di tempat alternatif (e) Apakah informan menginginkan atau karena sangat terpaksa melakukan aborsi dan Apa yang informan rasakan setelah melakukan aborsi (f) Apakah informan mengetahui dampak aborsi dan ancaman hukuman akibat melakukan aborsi (g) Apakah informan menyesal pernah melakukan hubungan diluar nikah sehingga berdampak harus melakukan aborsi? (bagi yang belum menikah) (h) Apakah setelah melakukan aborsi informan pernah mengalami mimpi buruk atau ada yang berubah dari hidup informan setelah melakukan aborsi.

Analisis data yang digunakan adalah analisis induktif deskriptif.

\section{HASIL DAN PEMBAHASAN}

Ada 10 informan pelaku aborsi provokatus kriminalis dengan status 5 orang belum menikah. Pertanyaan pertama tentang hubungan informan dengan keluarga semua menjawab baik. Dari 10 informan 5 orang mempunyai saudara $<5$ orang, 5 orang mempunyai saudara $>5$ orang. Dari 10 informan 2 orang masih tinggal dengan orang tua.

Dari 10 informan 9 orang mempunyai hubungan baik dengan suami / pacar, 4 orang terakhir berhubungan intim $<3$ bulan, 6 orang terakhir berhubungan intim $>6$ bulan dan semua informan menjawab bahwa pasangannya tidak menggunakan kondom saat berhubungan intim.

Dari 10 informan 4 orang mendapat reaksi marah dari keluarga saat mengetahui informan hamil, 6 orang informan merahasiakan dari keluarganya. Dari 10 informan 6 orang mengakui dipaksa oleh anggota keluarga untuk melakukan aborsi. 
Dari 10 informan 6 orang berasal dari kondisi ekonomi keluarga yang tidak mampu.

Dari 5 informan yang belum menikah ada bukti pengaruh pasangan untuk melakukan hubungan intim dan juga pengaruh teman.

Dari 10 informan, 8 orang berhubungan akrab dengan lingkungan sekitar dan 7 orang yang menceritakan kejadian tersebut kepada teman-temannya

Dari 10 informan, 5 orang yang pernah mendapatkan pengetahuan tentang pergaulan bebas.

Dari 10 informan tidak ada satu pun yang berhubungan dengan narkoba, minuman beralkohol dan merokok.

Dari 10 informan, alasan melakukan aborsi karena anak masih kecil 5 orang, karena takut ketahuan keluarga 2 orang, karena belum siap berkeluarga 2 orang, karena malu 1 orang.

Dari 10 informan, 7 orang melakukan aborsi $<1$ minggu, 3 orang $>1$ minggu,usia kehamilan saat melakukan aborsi $>3$ bulan sebanyak 7 orang dan $<3$ bulan sebanyak 3 orang.

Dari 10 informan, 8 orang merasakan takut saat melakukan aborsi dan 7 orang di antaranya merasakan sakit ketika melakukan aborsi.

Dari 10 orang informan, 9 orang pernah minum obat untuk mengugurkan kandungan dan 6 orang diantaranya pernah berusaha melakukan aborsi di tempat alternatif sebelum ke rumah sakit.

Dari 10 orang informan, 8 orang yang mengiginkan aborsi dan 2 orang karena terpaksa. Perasaan menyesal dan bersalah dialami 6 informan setelah melakukan aborsi.

Dari 10 orang informan, 7 orang mengetahui dampak atau bahaya aborsi dan 7 orang tidak mengetahui bahaya hukum melakukan aborsi.
Dari 5 orang informan yang belum menikah, 4 orang menyesal melakukan hubungan di luar nikah.

Dari 10 informan, 2 orang pernah mengalami mimpi buruk setelah melakukan aborsi dan 6 orang diantaranya merasa ada yang berubah dari hidupnya setelah melakukan aborsi.

Kehamilan diluar nikah di Indonesia dianggap sebagai aib dan suatu tragedi yang sangat tidak bisa diterima masyarakat maupun lingkungan keluarga. Usia menjadi pertimbangan seorang wanita memilih aborsi provokatus kriminalis. Apalagi untuk calon ibu yang merasa terlalu muda secara emosional, fisik belum matang, tingkat pendidikan rendah dan masih terlalu tergantung pada orang lain. Pada penelitian ini tampak pengaruh orang tua dan keluarga sangat dominan terhadap pengambilan keputusan untuk melakukan aborsi provokatus kriminalis dengan alasan memalukan keluarga atau aib bagi keluarga.

Kehamilan yang tidak diinginkan adalah penyebab perempuan ingin melakukan aborsi. Tidak selalu karena belum menikah, data studi yang dilakukan Perkumpulan Keluarga Berencana Indonesia (PKBI) menunjukkan bahwa sebagian besar perempuan yang ingin aborsi justru yang sudah menikah. Pada penelitian ini tampak peran suami sangat mempengaruhi seorang istri dalam mengambil keputusan untuk melakukan aborsi provokatus kriminalis dengan berbagai macam alasan diantaranya jumlah anak yang banyak,anak yang masih kecil,alat kontrasepsi yang gagal atau tidak cocok,kondisi ekonomi keluarga yang dianggap tidak cukup untuk membiayai kehidupan mereka jika mereka masih harus memiliki tambahan anak lagi. Hal ini sesuai dengan penelitian Lawrence et al. yang mengemukakan bahwa keputusan untuk melakukan abortus biasanya oleh berbagai macam alasan, antara lain tidak mau memiliki anak masa sekarang, 
masalah mitra dan ketidaksiapan menghadapi orangtua. ${ }^{5,6}$ Senbeto et al. juga menemukan bahwa faktor risiko terjadinya aborsi diantaranya adalah jumlah kehamilan, kegagalan kontrasepsi, status pendidkan, tempat tinggal dan status pernikahan. $^{7}$

Subjek yang melakukan aborsi provokatus kriminalis disebabkan oleh faktor internal dan eksternal. Faktor internal meliputi rasa cemas, takut membiayai anak yang kelak dilahirkan, dan takut karena telah membawa aib bagi keluarga pelaku aborsi provokatus kriminalis yang belum menikah. Adapun faktor eksternal yang mempengaruhi subjek melakukan aborsi provokatus kriminalis adalah adanya desakan dari keluarga atau teman yang mendorong untuk melakukan tindakan aborsi dan adanya dukun yang bersedia membantu melakukan aborsi provokatus kriminalis. Kedua faktor tersebut tidak berdiri sendiri, melainkan saling berinteraksi untuk mewujudkan perilaku aborsi provokatus kriminalis.

Tingkat aborsi provokatus kriminalis yang tinggi menyebabkan terjadinya perubahan kondisi sosial masyarakat karena dampak dari aborsi itu sendiri mempengaruhi kondisi mental dan psikis individu, keluarga, dan lingkungan yang bersangkutan. Dampak sosial yang bisa terjadi berupa pengucilan dan rasa stress yang berkepanjangan apabila tindakan tersebut diketahui lingkungannya. Aborsi provokatus kriminalis yang tidak aman juga dapat berpengaruh pada kesehatan pelakunya. Dari hasil penelitian ini tampak para pelaku aborsi provokatus kriminalis menjadikan alasan dampak sosial tersebut sebagai alasan untuk melakukan tindakan aborsi provokatus kriminalis

Budaya patriarki yang ada di Indonesia juga dipengaruhi dengan adanya sistem patrilineal. Patrilineal merupakan adat masyarakat yang mengatur alur atau garis keturunan dari pihak laki-laki atau ayah. Hal tersebut sudah sangat melekat di masyarakat dan secara tidak sadar budaya atersebut telah membingkai pemikiran masyarakat bahkan dalam tingkah laku seharihari. Tanpa kita sadari, budaya patriarki tersebut tidak hanya terjadi pada pasangan suami-istri, namun juga hubungan remaja yang masih berpacaran, khususnya dalam hal perilakau seksual dimana perempuan dipaksa oleh laki-laki untuk berhubungan seks dengan alasan sebagai pembuktian rasa cinta, dan apabila perempuan menolak, ia mengancam akan mengakhiri hubungan. Pada penelitian ini tampak pengaruh pasangan atau pacar dengan cara membujuk si perempuan untuk melakukan tindakan aborsi sehingga tidak diketahui oleh orang tua mereka.

Perempuan yang belum siap menghadapi kehamilan memutuskan untuk melakukan aborsi karena beberapa alasan yang menimbulkan inisiatif untuk melakukan aborsi provokatus kriminalis. Terlebih, nilai-nilai dalam lingkungan pertemanan yang menganggap bahwa aborsi provokatus kriminalis ilegal adalah hal yang wajar dilakukan apabila dalam kondisi terdesak, maka nilai-nilai tersebut akan dianut pula dalam diri pelaku.

Ada beberapa risiko yang diterima pelaku aborsi provokatus kriminalis, yaitu risiko ekonomi, fisik, psikis, dan sosial. Risiko fisik yang dialami antara lain pendarahan, perubahan bentuk fisik, serta turunnya daya tahan tubuh. Risiko psikis yang dialami antara lain rasa trauma, rasa bersalah, menyesal, namun juga lega. Proses aborsi provokatus kriminalis bukan saja suatu proses yang memiliki risiko tinggi dari segi kesehatan dan keselamatan seorang wanita secara fisik, tetapi juga memiliki dampak yang sangat hebat terhadap keadaan mental seorang wanita. Gejala ini dalam dunia psikologi dikenal sebagai "Post-abortion Syndrome". Gejala-gejala yang dialami antara lain kehilangan harga diri, berteriak histeris, mimpi buruk, ingin melakukan 
bunuh diri, mulai mencoba menggunakan obatobatan, tidak bisa lagi menikmati hubungan seksual. Dari hasil penelitian yang dilakukan, gejala psikologi hanya muncul pada 2 orang pelaku aborsi provokatus kriminalis, yang mengaku pernah mengalami mimpi buruk setelah melakukan aborsi provokatus kriminalis. Konsekuensi psikologis dari abortus telah sangat diabaikan. Beberapa hambatan membuat temuan yang terbatas. Berbagai jenis efek samping psikologis, namun, yang dialami oleh populasi penelitian memerlukan perhatian lebih intensif karena karakteristik kronis gangguan psikologis, dan dampak kesehatan wanita di keluarga dan kesehatan penduduk.

\section{KESIMPULAN DAN SARAN}

Abortus provokatus kriminalis banyak dilakukan oleh seorang wanita hamil, baik yang telah menikah maupun yang belum menikah dengan berbagai alasan. Peran orang tua untuk informan yang belum menikah dan peran suami untuk informan yang sudah menikah sangat dominan terhadap pengambilan keputusan melakukan tindakan abortus provokatus kriminalis dengan alasan aib bagi keluarga dan pertimbangan diantaranya jumlah anak yang sudah banyak, ekonomi keluarga yang dirasa masih kekurangan. Ada beberapa risiko yang diterima pelaku abortus provokatus kriminalis, yaitu risiko ekonomi, fisik, psikis, dan sosial. Berdasarkan asas autonomi, keputusan abortus yang diambil pada kasus abortus provokatus kriminalis adalah hak subjek (orang yang melakukan abortus provokatus kriminalis). Tetapi pada kasus abortus provokatus kriminalis ilegal, hal tersebut melanggar asas beneficience (asas manfaat), serta membahayakan kesehatan pelaku abortus provokatus kriminalis.

Saran untuk mengatasi masalah tersebut adalah (1) Meningkatkan peran orang tua dalam memberi batasan pergaulan dan ilmu agama yang lebih mendalam dengan harapan agar anak memiliki pegangan hidup dan tidak terjebak dalam kondisi tersebut, serta memberikan penyuluhan kepada para orang tua tentang bahaya melakukan abortus provokatus kriminalis (2) Memberikan penyuluhan kepada pasangan suami istri tentang resiko-resiko yang bisa terjadi akibat tindakan abortus provokatus kriminalis dan penggunaan kontrasepsi metode jangka panjang untuk menghindari kehamilan yang tidak diinginkan (3) Memberikan pendidikan kesehatan reproduksi dan bahaya bahaya yang bias terjadi akibat tindakan abortus provokatus kriminalis bagi remaja usia reproduksi, dan (4) Informasi dan edukasi tentang bahaya abortus provokatus kriminalis pada masyarakat dan resiko hukum yang akan di berikan kepada pelaku abortus provokatus kriminalis.

\section{DAFTAR PUSTAKA}

1. Sedgh $\mathrm{G}$ and Ball, Abortion in Indonesia, In Briefs, New York: Guttmacher Institude, No. 2, 2008.

2. Say L, Chou D, Gemmill A, Tunçalp O, Moller A, Daniels J, Gülmezoglu AM, and Temmerman M. Global causes of maternal death: a WHO systematic analysis, The Lancet Global Health, 2014, 2(6): e323-e333.

3. Finer LB, Frohwirth LF, Dauphinee LA, Singh S and Moore AM, Reasons US. Women Have Abortions: Quantitative and Qualitative Perspectives, Perspectives on Sexual and Reproductive Health, 2005, 37(3): 110-118.

4. Norris A, Bessett D, Steinberg JR, Kavanaugh $\mathrm{ML}$, De Zordo S, Becker D. Abortion Stigma: A Reconceptualization of Constituents, Causes, and Consequences, Women's Health Issues, 2011, 21(3): S49-S54

5. Saryono. Metodologi penelitian Kualitatif Dalam Bidang Kesehatan. Yogyakarta: Nuha Medika, 2010.

6. Senbeto, E, Alene G.D, Abesno N, and Yeneneh $\mathrm{H}$, Prevalence and associated risk factors of Induced Abortion in northwest Ethiopia. Ethiop.J.Health Dev, 2005, 19(1) 37-44

7. Pourreza, A. And Batebi A, Psychological Consequences of Abortion among the Post Abortion Care Seeking Women in Tehran, Iranian Journal of Psychiatry, 2011, 6(1):31-36. 